\title{
A Study of Impact of Tourism Direct Employment Trends on Tourism Arrivals: An Empirical Analysis of Sri Lankan Context
}

\author{
AMM. Mustafa ${ }^{1}$ \\ ${ }^{1}$ Faculty of Management and Commerce, South Eastern University of Sri Lanka, Oluvil, Sri Lanka \\ Correspondence: AMM. Mustafa, Faculty of Management and Commerce, South Eastern University of Sri Lanka, \\ Oluvil, \# 32360, Sri Lanka. E-mail: amustafa@seu.ac.lk
}

Received: July 16, 2019

Accepted: August 7, $2019 \quad$ Online Published: August 7, 2019

doi:10.5539/jpl.v12n3p62

URL: https://doi.org/10.5539/jpl.v12n3p62

\begin{abstract}
Sri Lanka is one of the major tourist attraction destinations in South Asian region. After the economic reforms in 1977, the successive governments implemented various attractive policies and programmes to promote tourism in pursuing economic growth and development. The government further employed a number of initiatives to encourage and attract tourism arrival in the country. In this backdrop, this study is to analyze the impacts of the tourism direct employment trend on tourism arrivals in Sri Lankan context by using the time series data from year 1978 to 2017. The dependent variable used in this study is tourism arrivals. The independent variables are tourism direct employment and tourism Earnings. The tools used to achieve the objective of this study are Correlation Analysis, Multiple Regression, and Residual test. In this study, it is found that the correlation relationship between the variables is very strong. tourism direct employment and Tourism Earnings are directly related with tourists' arrivals. The data collected have analyzed by using the econometrics software EViews 10 . Based on the result recommended that to increase the magnitude of the direction tourism arrival in Sri Lanka, the factors such tourism direct employment and tourism Earnings should play statistically significant roles. This significant role should be considered by the relent authorities in Sri Lanka.
\end{abstract}

Keywords: tourists arrivals, tourism direct employment, tourism earnings

\section{Introduction}

Though there are various definitions for tourism, the World Tourism Organization (WTO) has defined tourism as "travelling to and staying in places outside their usual environment for more than twenty four (24) hours and not more than one consecutive year for leisure, business and other purposes not related to the exercise of an activity remunerated from within the place visited". Thus, the tourism is connected with a combination of the activities, the industries and the services that distribute a travel experience with the inclusion of retail shops, eating and drinking establishments, accommodation, entertainment facilities, transportation and other hospitality services supplied for individuals or groups of individuals who are travelling away from their homes (UNWTO, 2014). Very broadly in general, the extent of employment opportunity in tourism industrial sector is very widespread, and the most of these employment opportunities and potentials are still highly unused in many of the tourist destination countries. There are career opportunities in public and private sectors due to this tourism sector. There are the opportunities found in the public sector in the departments of tourism such as directors, officers, assistants, tourist guides, and information assistants and so on. The professionals with the tourism-oriented qualifications are greatly demanded in the private sector rather than in the public sector in Sri Lanka. Travel \& Tourism industry is one of the prime job creators in the world. The industry employs more than 98 million people directly, 1 representing over 3 percent of all employment. When indirect and induced impacts are included, the industry contributes to around one in every eleven jobs worldwide. The share of world employment in Travel $\&$ Tourism is greater than that for the auto manufacturing and chemicals manufacturing industries combined, across every region of the world. Furthermore, the outlook for the industry is relatively positive: job growth in Travel \& Tourism is forecast to average 1.9 percent per year over the next decade, compared with 1.2 percent annual growth forecast for total jobs in the global economy (Rochelle, 2013). In Sri Lanka, the total persons who have been directly employed in the tourism industrial sector is accounting to 135,930 in year 2015. It recorded an increase of $4.7 \%$ over the last year. Most of the employees have been employed in catering and accommodation sectors being connected to tourism industrial sector in the country. This amount of magnitude is 
recorded as $80.6 \%$ of the total direct employment opportunity, representing a considerable increase of $4.3 \%$ compared to the previous year 2014 in which it is amounted to 105,001 . Because of the situation of registering process of more Tour Operators and Travel Agents, the opportunity of employment in these sectors has been recorded further as 9483 which represents an increase of $4.3 \%$ when compared to the previous year 2014.

The total amount of 6,369 direct employments has been recorded in year 2015 under the Air Line sector in Sri Lanka. It indicates an increase of $7.2 \%$ in the total direct employment generated from the entire tourism sector in Sri Lanka. In the meantime, the capacity of employment generated from the institutions which provide the recreational facilities has been improved to an increase of $11.5 \%$ of the total employment on account of the total employment created from the tourism sector. Further, an amount of tourist guides has been increased to a number of 4,590. This record also is an increase of 3.8\% compared to the previous year (2014). The employment of 1,796 has increased in the Tourist Shops in 2015 in comparison with the amount of 1,680 in year 2014. The total direct employment generated from the categories such as technical, clerical and supervisory sectors has been incased mainly but the improvement in these categories is marginal in the increase of 3.6 in comparison with year 2014. The employment recorded in these sectors is amounting to 51.4 percent which is more than half of the direct employment generated from the tourism sector in Sri Lanka. The categories such as manual and operative grades are sharing to the amount of 34 percent of the total employment and the rest of 14.6 percent is recorded from the category of managerial grades. The total indirect employment generated from the tourism sector in 2015 has been estimated to the amount of 183,506 in the supplying sector in the country of Sri Lanka. The increase in both direct and indirect employment in year 2015 is amounting to 319,436 on account of the increased arrivals of tourists in year 2015. This improvement in the direct and indirect employment is a gradual increase of 6.5 percent compared to the previous year 2014 in which this figure is amounting to 299,890 . The nature of ratio between the generation of direct and indirect employment is estimated at one job for 5.6 arrivals of tourism in 2014 in the country. This nature of ratio shows an increase of one job for every four arrivals of tourists in 2015in the country in comparison with year 2014 because of the new technology used in the establishment of tourism and more arrivals of tourists (Sri Lanka Tourism Development Authority, 2017).

Tourist arrival to a country indicates that in the course of the trip or in the course of the different trip of a tourist, every single entry of a particular tourist to a particular country crossing the border of the country on her or his visit prolongs at least a night in the particular country. The term "International Visitor" indicates that a person who is traveling to a country outside the usual environment for a particular period not less than 12 months and the purpose of the visit is not to earn remuneration from the country visited. "International Tourist/ Overnight Visitor" indicates that an International Visitor who is staying at least one night in the country visited. "International Excursionist/Same day Visitor" indicates that an International Visitor who is not staying a night in the country visited. In general, the arrivals of tourism in the destinations of tourism all over the world arena are estimated at 1,184 million in 2015. It represents an increase of 4.4 percent compared to the previous year (2014). As more than 51 million of tourists are travelling around, the overall demand from such number of tourists has been valued highly. In particular, the post war scenario is uninterruptable to attract more tourists every year and also make year 2015 as remarkable in recording the increase of 4 percent of international arrivals of tourists. Accordingly, the economic growth of the countries and the creation of jobs in the various parts of the world are contributed due to the instrumental performance of the tourism sector. As a result, the promotion of policies in connection with sustainability, human resource development, and the facilitation of travel advancing the persistent economic growth of tourism is essential for the countries all over the world. Rs. 405,492 million is estimated as the earnings received from tourism sector in Sri Lanka in year 2015 in comparison with year 2014. It represents an increase of $28 \%$ compared to year 2014. The estimation of the earnings on the basis of US Dollar from the tourism sector in the country is US\$2,980.6 million. This earning is estimated at US\$2,431.1 million for year 2014. It shows an increase of 23 percent of total earnings of tourism sector. And also, the Per Capita Tourist Earning is estimated at US\$ 1,657 in 2015. It represents an increase of 4.1 percent in comparison to 2014 estimated at US\$ 1592. Per day Per Capita Tourist Earnings is estimated at US\$164.1. It represents an increase of 2 percent in year 2015 in comparison to US\$ 160.8 in year 2014. As a result, one of the key sources in earning foreign exchange in the economy of Sri Lanka is the tourism sector (Sri Lanka Tourism Development Authority, 2017).

\section{Literature Review}

Khathi (2001) aimed to explore the positive impacts of tourism on the creation of employment and the capacity of tourism sector to improve other related sectors in South Africa using the descriptive analysis by collecting the secondary data from the secondary sources. He found that the extensive number of employments could be created by improving the tourism sector in the country. As most of the tourism operations in the country were 
subject to the labour intensive, it is potential so as to create more employment opportunities within the country. Further, he concluded that the other sectors in the country were stimulated to be developed due to the improvement in the tourism industrial sector.

Duma Nomonde and Okem Andrew Emmanuel (2017) examined the roles of the annual Durban Tourism Careers Expo and the Tourism Indaba in connection with the creation of employment opportunities by employing the qualitative methodology in which a sample of 16 respondents were selected to interview face to face so as to find the objectives of the study. They found that the events such as the annual Durban Tourism Careers Expo and the Tourism Indaba created more employment opportunities among the youngsters. The youngsters were exposed in the industry and encouraged by them so as to initiate own businesses. Sintayehu et al. (2016) aimed to outline the information about the employment opportunities of tourism by employing qualitative approach (narrative review) by collecting data from the secondary sources. They found that the employment opportunities created by Tourism and hospitality creates are diversified in the various sectors such as food and beverage establishments, accommodation, travel agencies, transportation services, natural and cultural attractions sites, and tour operation companies.

\section{Methodology}

The time series data used for the analysis of this study are collected from the Annual Report of Sri Lanka Tourism Development Authority - 2017. The time series data cover the period of time from 1978 - 2017 Thus, the following model is constructed and tested to achieve the objective of the study.

$$
\begin{gathered}
\mathrm{TA}=f(\mathrm{TDE}, \mathrm{ET}) \\
T A_{t}=\delta_{0}+\delta_{l} T D E_{t}+\delta_{2} E T_{t}+\varepsilon_{t}
\end{gathered}
$$

Where:

$$
\begin{aligned}
& T A_{t}=\text { tourist arrivals, } T D E t=\text { tourism direct employment from tourism sector, and } \\
& E T_{t}=\text { earnings of tourism. } \delta_{0}, \delta_{1}, \delta_{2}=\text { the coefficients of the model and } \varepsilon_{t}=\text { error term }
\end{aligned}
$$

\section{Data Presentation and Analysis}

Time series data used 1978-2017 period Sri Lanka behavior of variables tourist arrivals, tourism direct employment and earnings of tourism nonparametric approach

Tourism Arrival 1978-2017

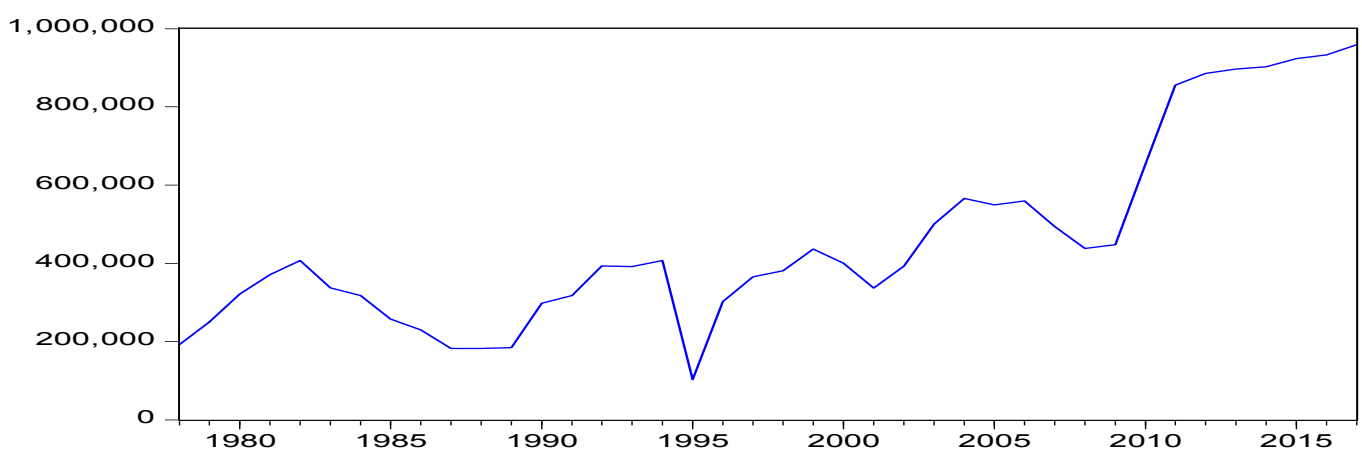

Figure 1. Trend of tourist arrivals 1978-2017

Tourism Direct Employment 1978-2017

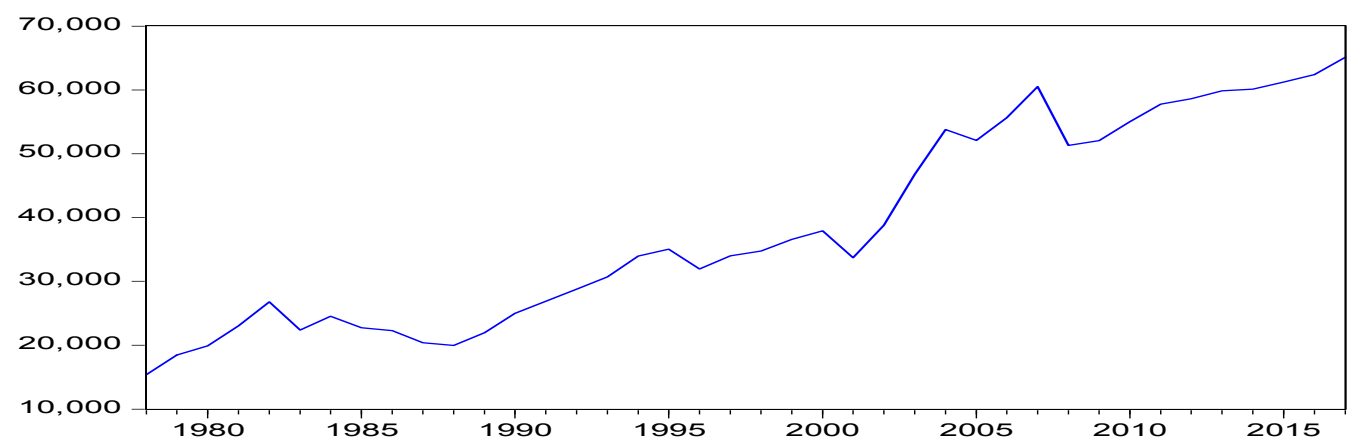

Figure 2. Trend of tourism direct employment 1978-2017 
Earnings of tourism 1978-2017

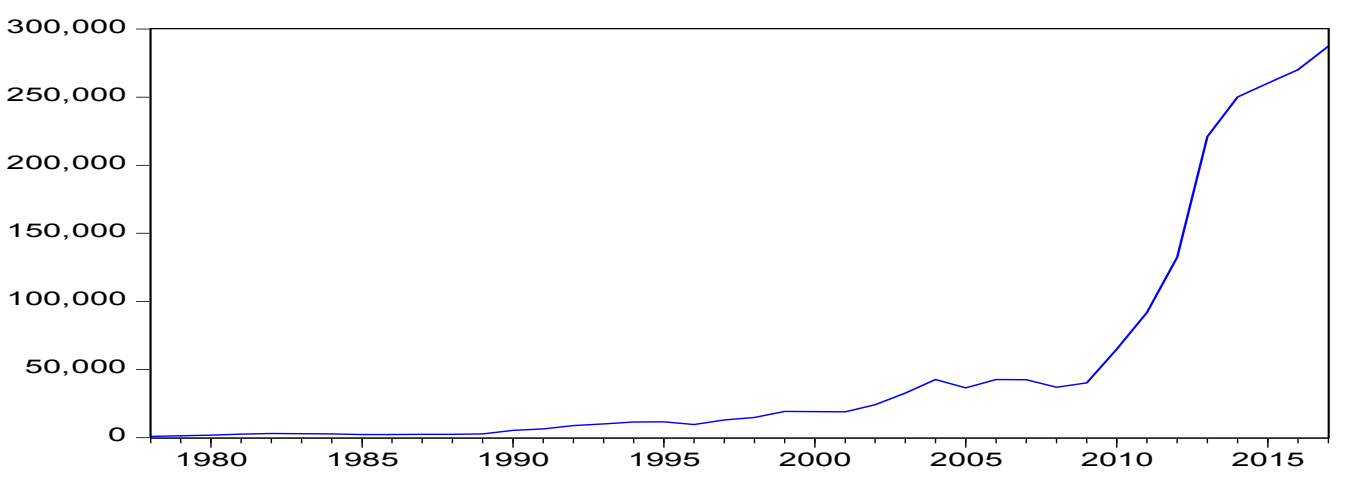

Figure 3. Trend of earnings of tourism 1978-2017

Correlation Analysis: The correlation results of the time series data used in this study. All the independent variables such as TDE, and ET are correlated with the dependent variable such as TA at 0.0005 percent significant level $(p<0.0005)$. All the independent variables are positively correlated with the dependent variable.

Table 1. Multiple regression model - dependent variable: tourists arrivals (TA)

\begin{tabular}{ccccc}
\hline Model & Coefficients & Std. Error & t-Statistics & Prob. \\
\hline (Constant) & 91326.55 & 64846.48 & 1.408350 & 0.1676 \\
Tourism Direct Employment (TDE) & 7.622758 & 1.931777 & 3.945983 & $0.0004^{*}$ \\
Tourism Earrings(ET) & 1.413679 & 0.359019 & 3.937621 & $0.0004^{*}$ \\
\hline
\end{tabular}

*Significant at $1 \%$

$$
\mathrm{TA}_{\mathrm{t}}=91326+7.6227 \mathrm{TDE}_{\mathrm{t}}+1.4136 \mathrm{ET}_{\mathrm{t}}
$$

Regression results: According to the regression results delineates the results of model summary of the regression model. In the summary of the model, adjusted $R$ Square and Durbin Watson Statistic are studied. According to the value of adjusted Square, it is noted that the value of $R^{2}$ is higher than $0.60\left(R^{2}>0.60 / 60 \%\right)$. It is 0.916 which represents the $91.6 \%$ of internal factors which are influencing on the impacts of the dependent variables - TA to tourism industrial sector in Sri Lanka. Only $8.4 \%$ of the external factors are influencing on the determination of TA other than all the contribution of independent variables. The value of Durbin Watson Statistics is 1.78, reduce multicolinearity in this multiple regression model. Coefficients of the Multiple Regression model. Each of the independent variables is having the unique value of the coefficients of the independent variables. The dependent variable in this model is TA to the tourism industrial sector in Sri Lanka. The independent variables of this model TDE and ET are having statistically significant relationship with the dependent variable at one percent level. The regression model predicts that one unit of increase in TDE leads to increase the TA by around 7.62. Thus, there is a positive relationship between these two variables and statistically at $1 \%$ significant level. If there is one unit increase in ET there will be around 1.41 units of increase in the TA and there is a positive relationship between these two variables. 
Confidence Ellipse- relationship between tourist arrivals, tourism direct employment and earnings of tourism

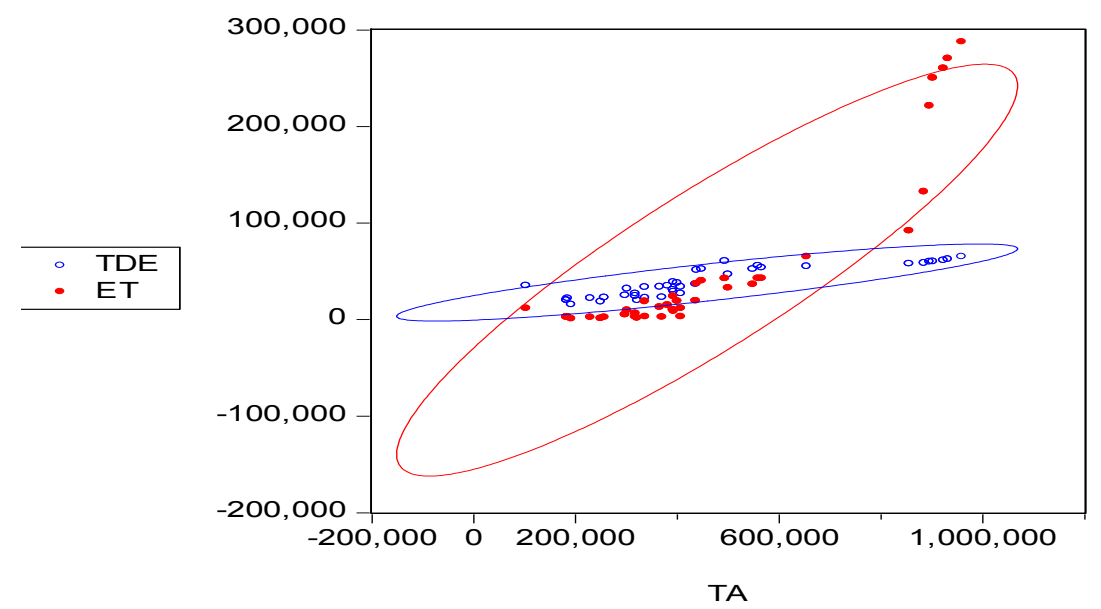

Figure 4. Confidence ellipse TA-TDE and TA-ET

Figure 4 which is depicting the graphical representation of the variables used in this study is especially significant so as to find the trend and the principal connection between the variables such as TDE and TA. Relationship positive is shown by the graph of Confidence Ellipse between the variables such as TDE and TA. In addition, it is found that the variables such as ET and TA are correlated. The Confidence ellipse graph shows that the direct relationship between ET and TA.

\section{Kernel Fit and Confidence Ellipse - relationship between tourist arrivals, tourism direct employment and} earnings of tourism

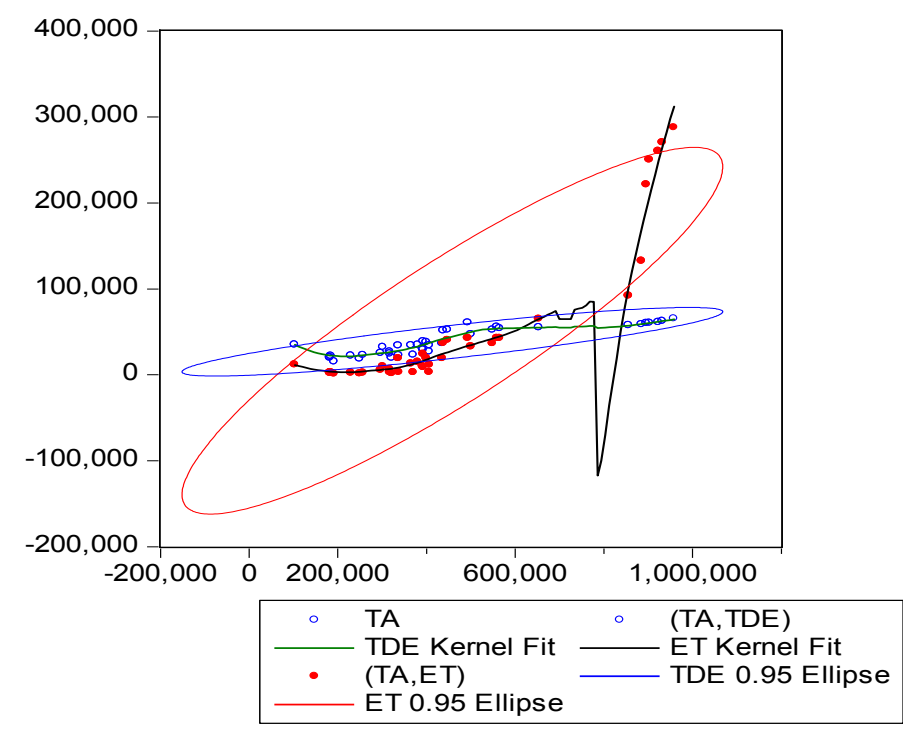

Figure 5. Kernel fit and confidence ellipse TA-TDE and TA-ET 
Nearest Neighbor Fit and Confidence Ellipse - relationship between tourist arrivals, tourism direct employment and earnings of tourism

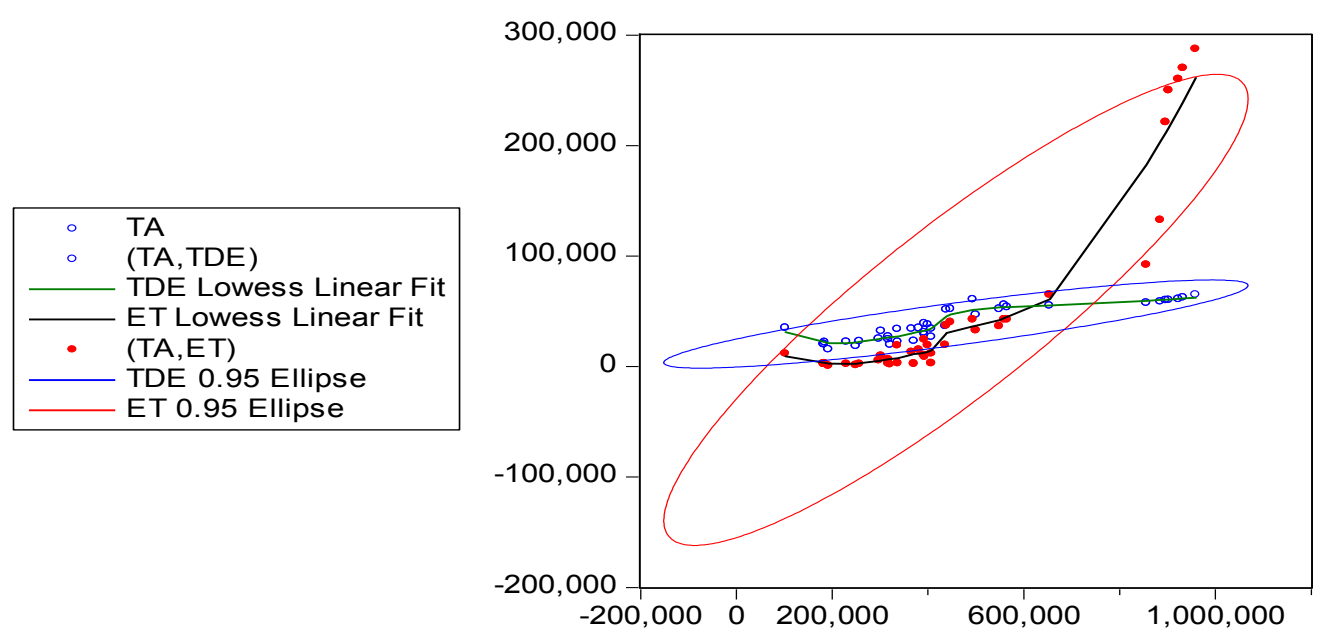

Figure 6. Nearest neighbor fit and confidence ellipse TA-TDE and TA-ET

Above Figure 6 data used in this study is very helpful to find out the movement and fundamental relationship between the variables TDE and TA. The Nearest Neighbor and Confidence Ellipse graph indicate that the direct relationship between ET and TA.

\section{Stability Diagnostics for Model:}

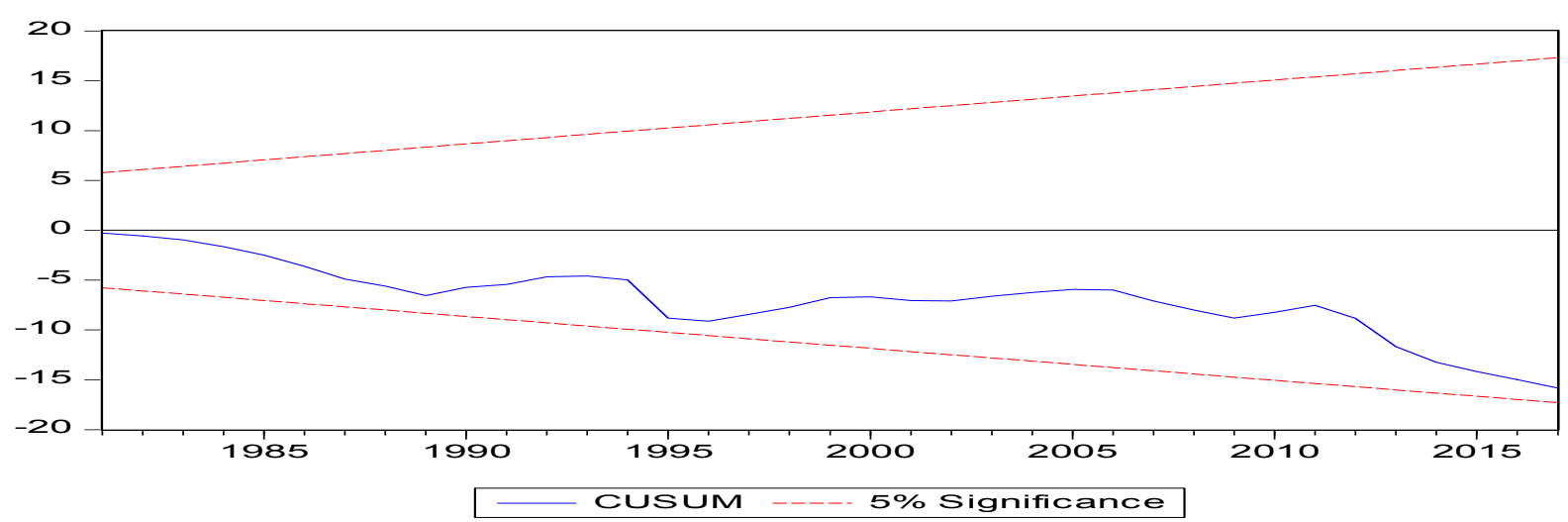

Figure 7. Cusum - model stability test

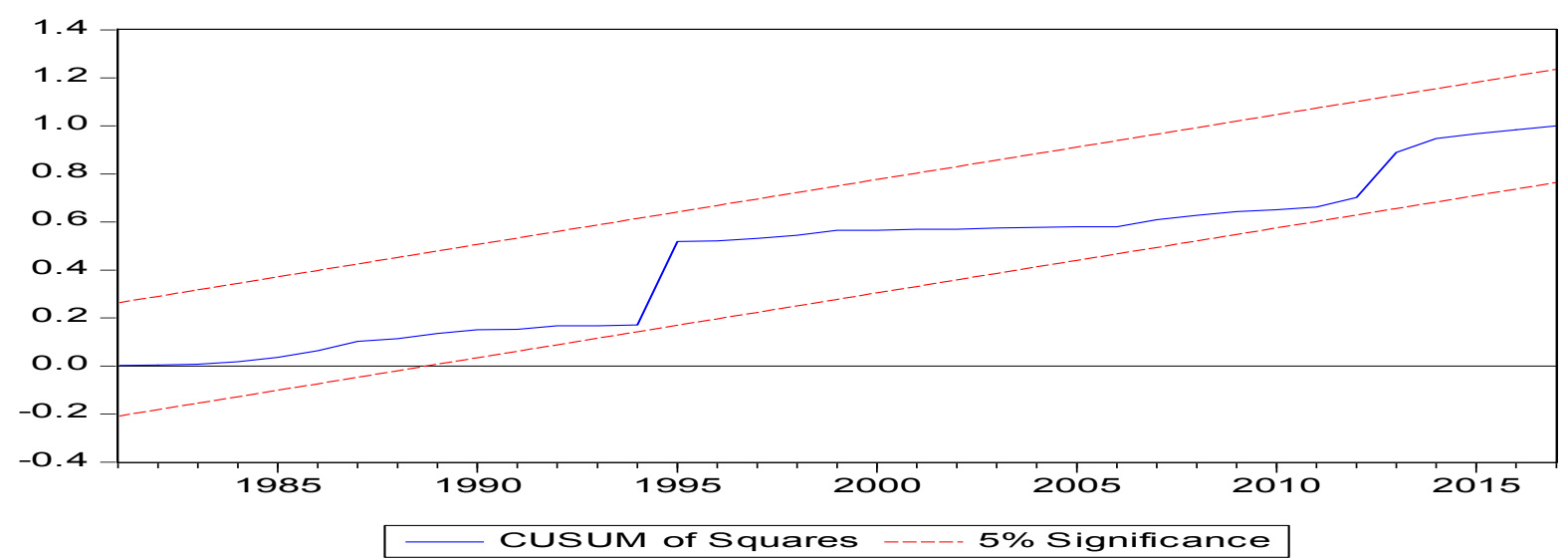

Figure 8. Cusum of squares- model stability test 
Stability of the parameters is examined by the test of Cumulative Sum and Cumulative Sum of Squares with the use of recursive residuals. Since the statistical plots are located within the critical boundary at the both tests at $5 \%$ level of significance, the hypothesis of "the regression equation is correctly specified" is confirmed. Therefore, it is evident that the parameter is stable. The diagnosis of residual analysis with respect to heteroskedasticity, normality test, and autocorrelation shows that the results are robust

\section{Conclusion}

Tourism arrival plays a significant role in expanding the tourism sector in Sri Lanka. The tourism industry provides tremendous opportunity to the country in terms of contribution to tourism receipts, employment generation. At present, the government policies focus to increase tourist arrivals in the country and facilitate investments in tourism infrastructure, would lead to significantly higher multiplier effect on the key economic parameters of the Sri Lankan economy. As per the correlation analysis, all the independent variables are positively correlated with the dependent variable. The correlation relationship between the variables is very strong significant at one percent level. Internal factors are influencing on the impacts of the direct employment generated from the sources of the tourism industrial sector in Sri Lanka. The value of the independent variables such as tourists' arrivals, tourism earrings significantly raises the influences the tourism direct employment. That is, the independent variables play significant roles on the dependent variable.

\section{Recommendation}

Sri Lankan government could formulate a policy framework to support for investors and other industry to increase the tourist's arrival to Sri Lanka. For this task, policies can be formulated in various level such as simplification of licensing procedures, reduction of the high electricity tariffs, unification of the regulatory environment and creating a single authority for tourism promotion, creating opportunities to promote shopping of internationally reputed branded products and entertainment, simplification of the investment approval process for tourism related investments, attracting internationally reputed tourist hotels and resorts, and environment-friendly, clean-city concept for urban development. It is further recommended that any of the stakeholders or policy makers or government of Sri Lanka can be aware of the findings of this study. To increase the magnitude of the direct employment in Sri Lanka, the factors such tourist arrivals, excursionist arrivals, and earnings should play significant roles. This significant role should be considered by the relevant authorities in Sri Lanka. Of the significant factors, the earnings are the prime factor which influences considerably the tourism direct employment generated. This is one of other concerns that should be taken into consideration in achieving the macroeconomic objective of full-employment level in Sri Lanka through the improvement of the tourism sector.

\section{References}

Duma, N., \& Okem, A. E. (2017). Youth Entrepreneurship and Employment through Tourism: A Case Study of the Durban Tourism Expo and Indaba. African Journal of Hospitality, Tourism and Leisure, 6(1). Retrieved from http//:www.ajhtl.com

Khathi, M. G. (2001). Investigating the Potential for Job Creation in the Tourism Industry with particular reference to Disadvantaged Communities. Economic Policy Research Institute. Retrieved from www.basicincome.org/bien/pdf/rp13

Rochelle, T. (2013). Travel \& Tourism as a Driver of Employment Growth, World Travel \& Tourism Council. Retrieved from http://www3.weforum.org/docs/TTCR/2013/TTCR_Chapter1.5_2013.pdf

Sintayehu, A., Kassegn B., \& Sewent, T. (2016). Employment Opportunities and Challenges in Tourism and Hospitality Sectors. Journal of Tourism \& Hospitality, 5(6). Retrieved from https://www.omicsonline.org/open/access/employment/opportunities/and/challenges/in/tourism/and-hospital itysectors/2167/0269/1000257.php/aid=82923

Sri Lanka Tourism Development Authority. (2017). Annual Statistical Report - 2015, SLTDA.

UNWTO and ILO. (2014). Measuring Employment in the Tourism Industries - Guide with Best Practices. UNWTO, Madrid, Spain. Retrieved from https://www.e/unwto.org/doi/pdf/10.18111-9789284416158

\section{Copyrights}

Copyright for this article is retained by the author(s), with first publication rights granted to the journal.

This is an open-access article distributed under the terms and conditions of the Creative Commons Attribution license (http://creativecommons.org/licenses/by/4.0/). 